\title{
EL ATLAS DE LA OBRA DE BULLOCK
}

\section{$\mathbf{P} \mathbf{O}$}

\section{JUST I NO FER N A D E Z}

ENTRE las visiones más o menos fantásticas de que México ha sido E objeto en todos los tiempos, cuando provienen de extranjeros, se encuentra la de Mr. William Bullock, súbdito inglés que pertenece a la avalancha que con estas o aquellas intenciones, visitó nuestro país en la primera mitad del siglo xIx, una vez lograda la Independencia. Es bicn conocido su libro titulado "A Six month's residence and travels in Mexico..." (1824), ${ }^{1}$ en el cual incluyó una serte de litografías, un plano de la ciudad de México y un grabado del llamado "Plano de papel de maguey", que había llevado a Londres junto con otras antigüedades mexicanas y que exhibía en su Museo mexicano establecido en la capital de Inglaterra.

El mismo año en que apareció la edición inglesa del libro de Bullock, vió la luz también otra en francés, publicada en París $^{2}$ y que se completa

1 Bullock, W. A Six Month's Residence And Travels in Mexico; Confaining Remarks on the Present State of New Spain, Its Natural Productions, State Of Society, Manufactures, Trade, Agriculture, And Antiquities, etc. With Plates And Maps, By ..., F. L. S. Propietor of the late London Museum London: John Murray. 1824 (En el Catálogo de la Lib. Porrúa Hnós. y Cía. México, 1949. N $6150)$.

2 Bullock, W. A. Le Mexique En 1823, on Relation D'Un Voyage Dans La Nouvelle Espagne, contenat des notions exactes et peu connues sur la situation Par. M. Beulloch, Propiétaire du Musée mexicain établi á Londres; Ouvrage traduit de l'anglais par M. Précédé d'une introduction, et enrichi de pièces jus- 
con un Atlas pour servir an Mexique en 1823. Paris, 1824, que hoy día es difícil de adquirir [1]. * Además, el entusiasta de México presentó dos años después, también en Londres, un Panorama con vistas de la ciudad de México, reproducidas a colores por los señores Burford. ${ }^{3}$

La visión de México de Bullock entra a ocupar su sitio en el gran tema que ha venido desarrollando Ortega y Medina con el título de: "México en la conciencia anglosajona". * Mas una de las formas en que México se presentó a esa conciencia, y a la europea en general, fué por medio del arte $y$ como este es nuestro interés me ha parecido conveniente fijar la atención en las láminas que componen el Atlas de la edición francesa. ${ }^{5}$ Se sabe que los dibujos originales de las litografías fueron de mano de Mr. Bullock Jr., quien acompañó a su padre en su viaje a México, así, interesa ver cómo interpretó el paisaje, los tipos $\mathrm{y}$ trajes y algunas antigüedades mexicanas. No es fácil decir hasta qué punto los dibujos originales sufrieron modificaciones por los delineantes: Boquet, Lepinoy y Brisou, o por el litógrafo Marlet; lo cierto es que resulta difícil admitir que Bullock Jr. hubiera dibujado, o visto, algunas cosas que resultan desconcertantes. En todo caso no parece que fuera "un estupendo dibujante", sino, más bien, un modesto aficionado. Hay algo extraño y es que las "vistas", con paisaje, parecen ser de una mano y los tipos y trajes, de otra. Quizá sus "apuntes" fueron interpretados

tificatives et de notes; Par Sir John Byerly. Paris, Alexis-Eymery, Libraire. 1824. 2 Vols. (En el Catálogo de la Lib. Porrúa Hnos. y Cía. México, 1949. N 6151, sin el Atlas).

* Los números entre corchetes corresponden a las ilustraciones, según el orden en que aquí se reproducen.

3 Description or view of the city of Mexico and surrounding country noze exhibing in the Panorama, Leicester Square. London, 1826. Nueva edición en Filadelfia en 1833 (noticia tomada de Ortega y Medina).

Véase: Romero de Terreros, Manuel. Apostillas Históricas. México, 1945, pp. 155 a 160. "México visto por un inglés en 1823".

4 Ortega y Medina, Juan A. Mexico en la conciencia anglosajona. ler. Vol. México, 1953. México y lo Mexicano, $\mathrm{N}^{\circ}$ 13. Porrúa y Obregón, S. A. $2^{\circ} \mathrm{Vol}$. México, 1955. México y lo Mexicano, $N^{\circ} 22$. Antigua Librería Robredo.

Se recomienda la lectura de esta interesante investigación.

5 Atlas pour servir au Mexique en 1823. Paris, 1824. Alexis Eymery, Rue Mazarine, $\mathrm{N}^{\bullet} 30$, et a Bruxelles, chez Brunet et Charles Fruger. $(20$ × $26 \mathrm{cms}$. cartoné). Adquirido para la Biblioteca del Instittuo de Investigaciones Estéticas. 


\section{ATLAS HISTORIDUE}

Gionr setwir an Siflexique en 1823 ,

\section{- brecloxplication des planches.}

\section{PARIS,}

dolexia Eymery, Brue Mazarine, $\% \cdot$

$$
\text { Git a Bruaclles, chez Verumet of Cbardew frugev. }
$$

1. Portada del Atlas. 
DOI: http://dx.doi.org/10.22201/iie.18703062e.1956.24.60o

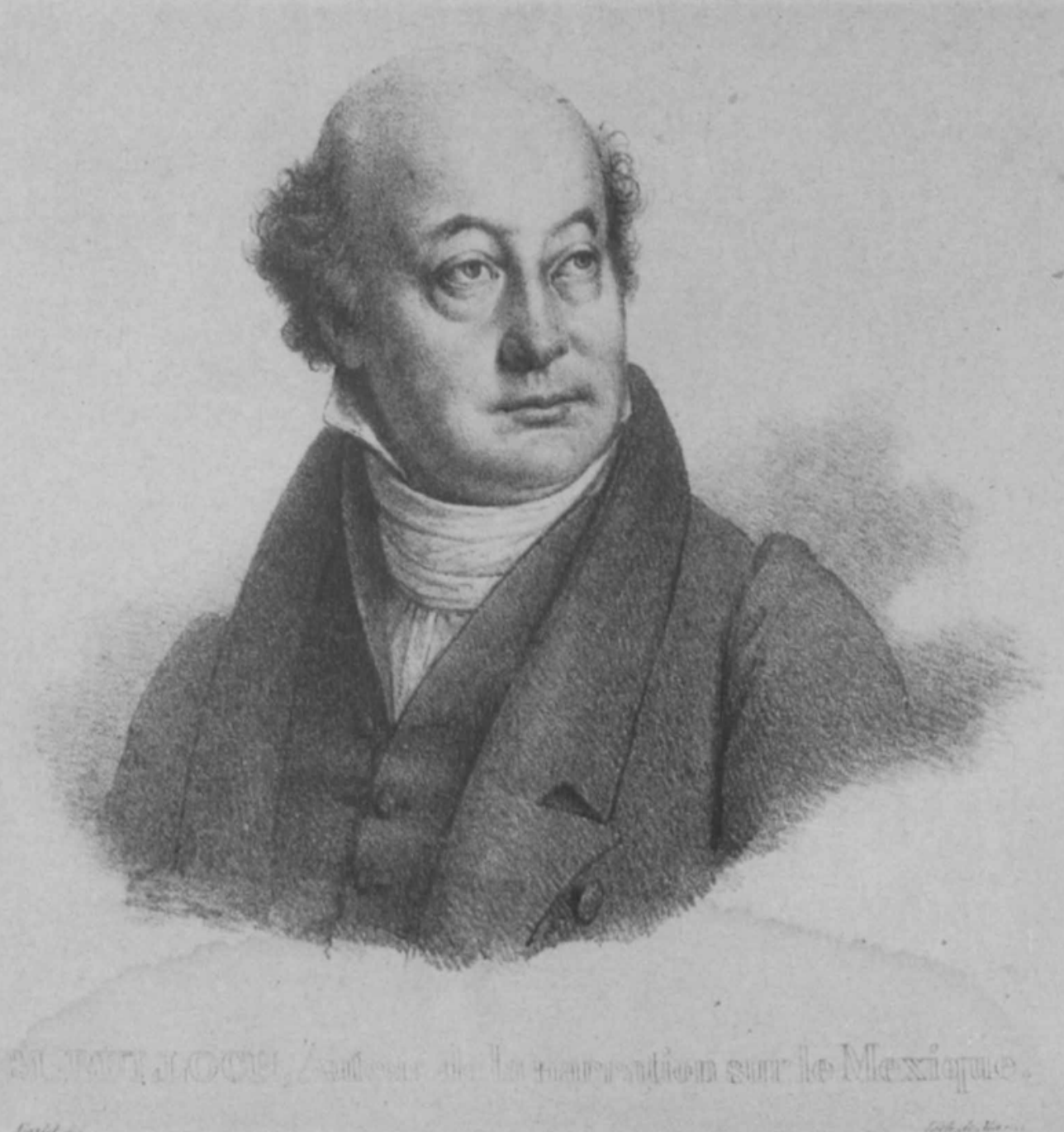

2. Retrato de William Bullock. 
DOI: http://dx.doi.org/10.22201/iie.18703062e.1956.24.6oo

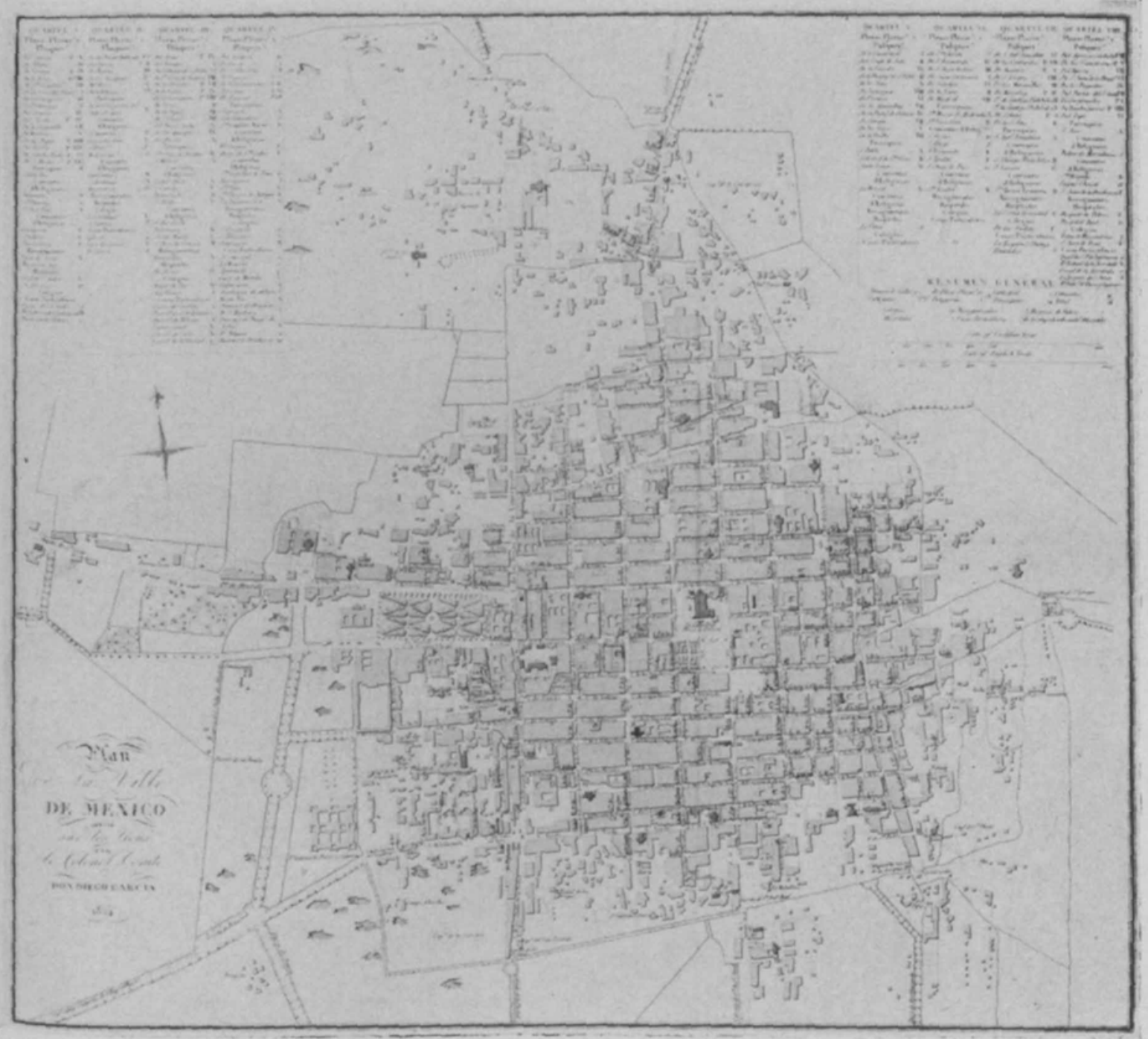

3. Plano de la ciudad de México. 1824. Grabado. 


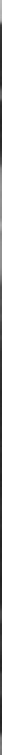

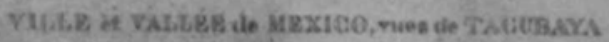

4. Panorama de la ciudad y del Valle de México. 


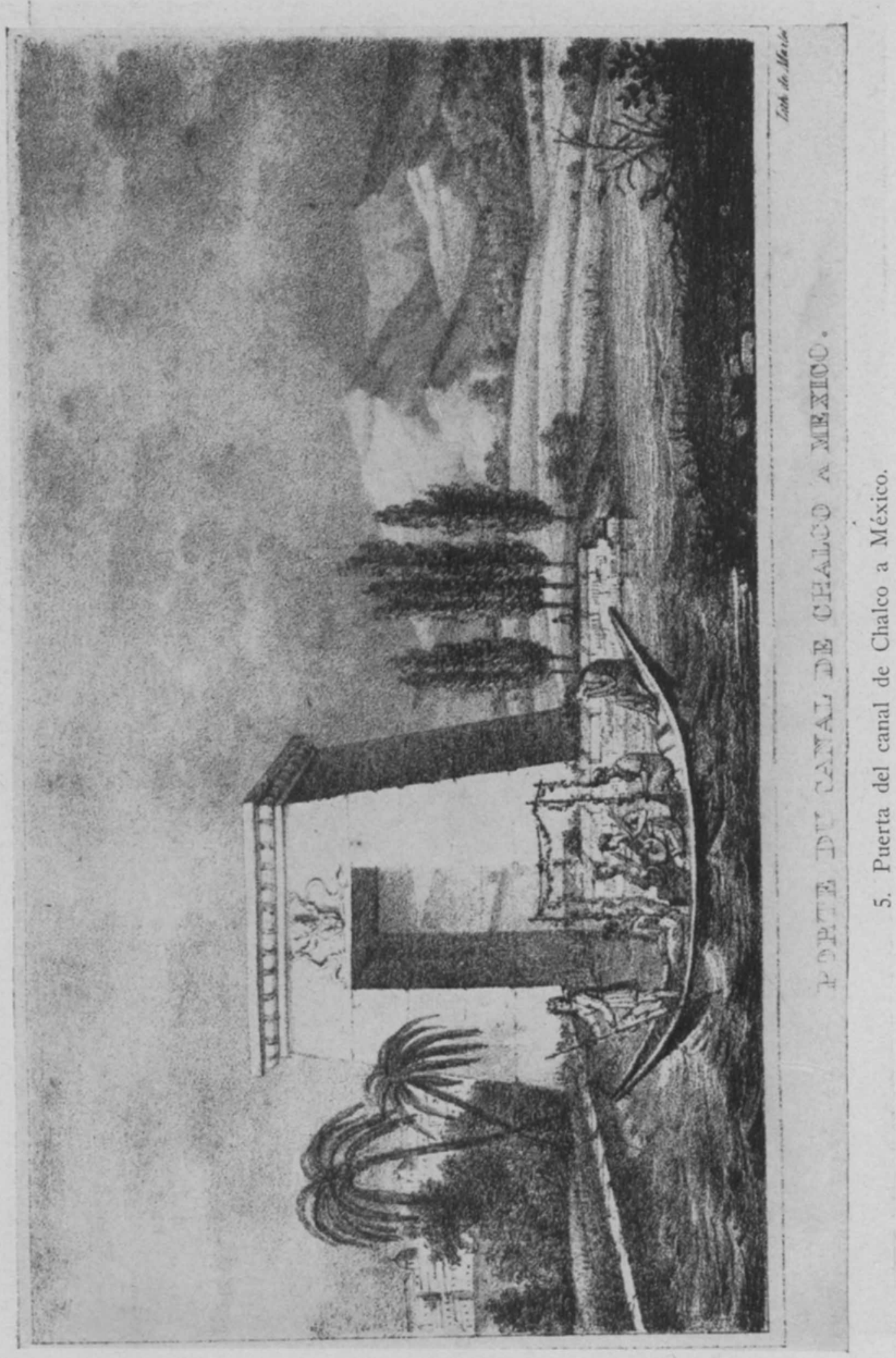


DOI: http://dx.doi.org/10.22201/iie.18703062e.1956.24.6oo

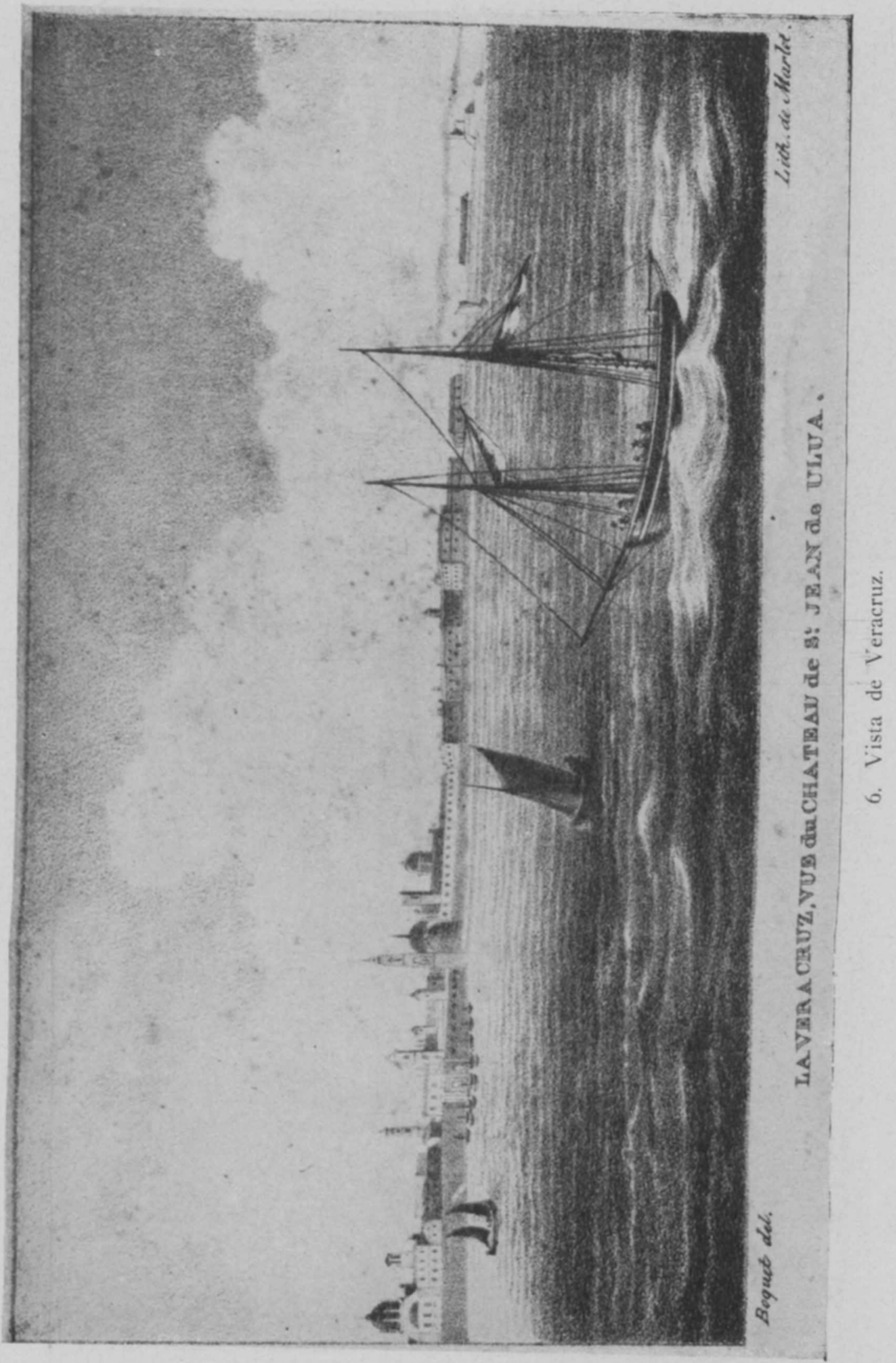




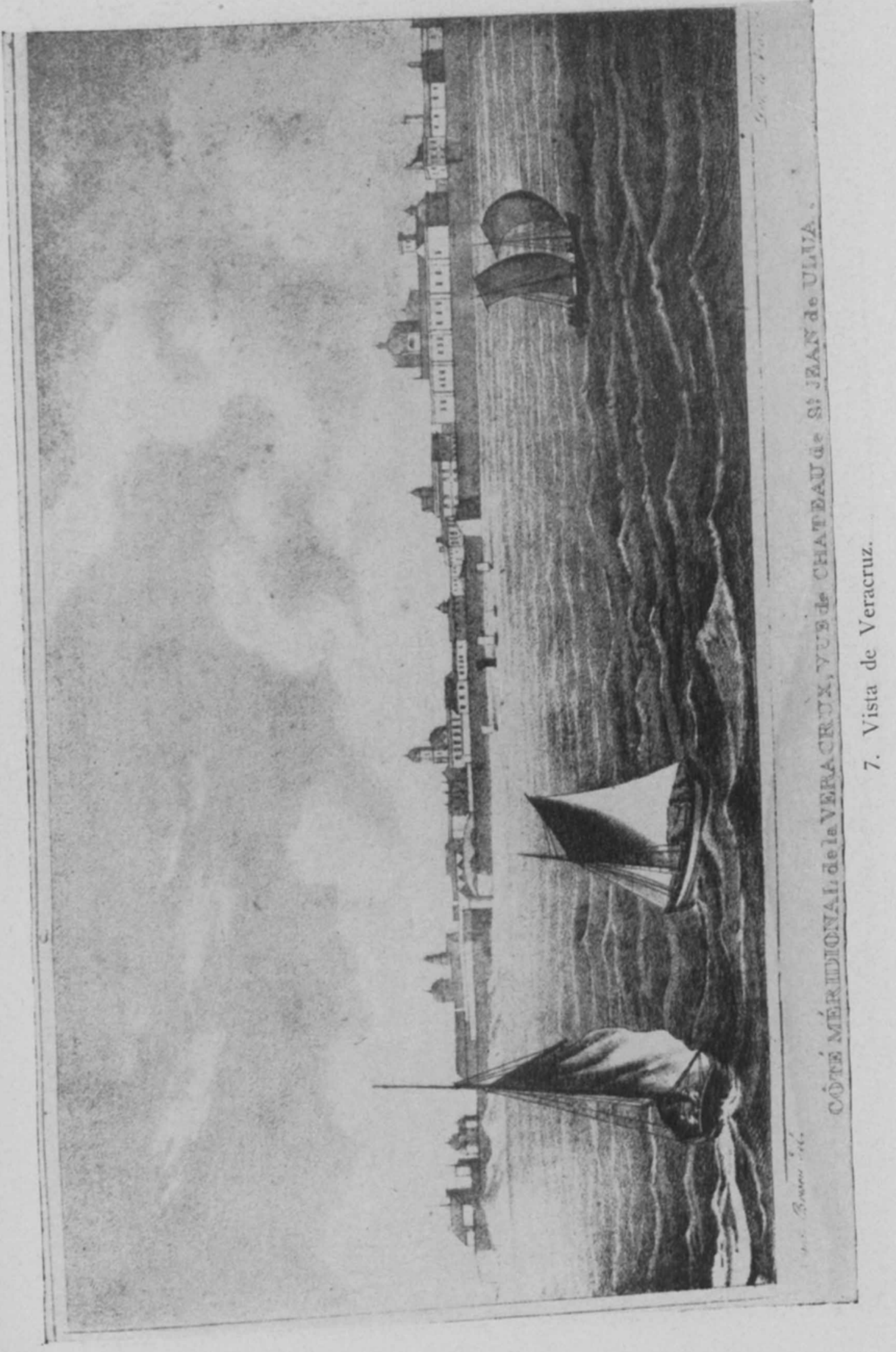


DOI: http://dx.doi.org/10.22201/iie.18703062e.1956.24.6oo

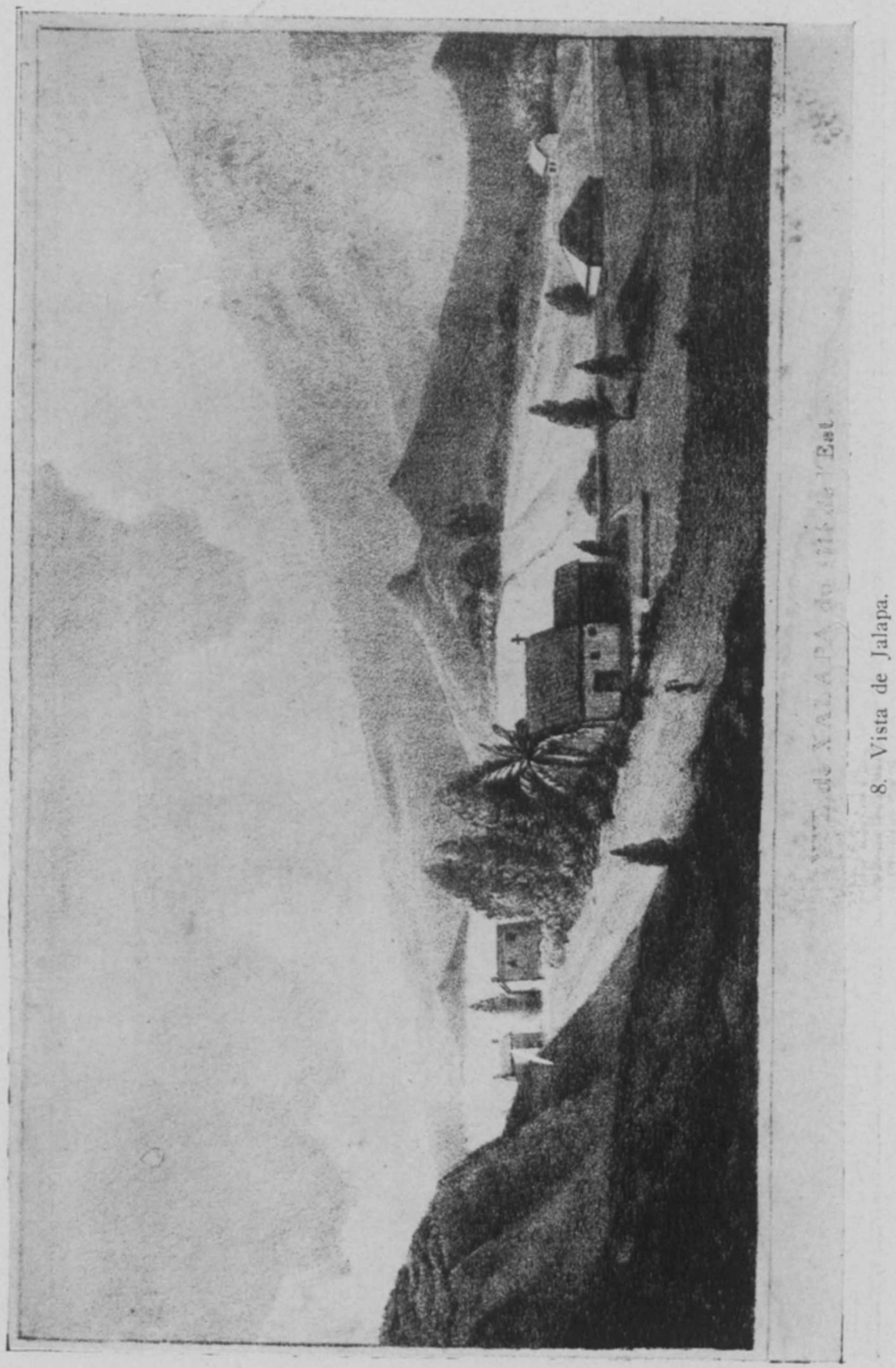




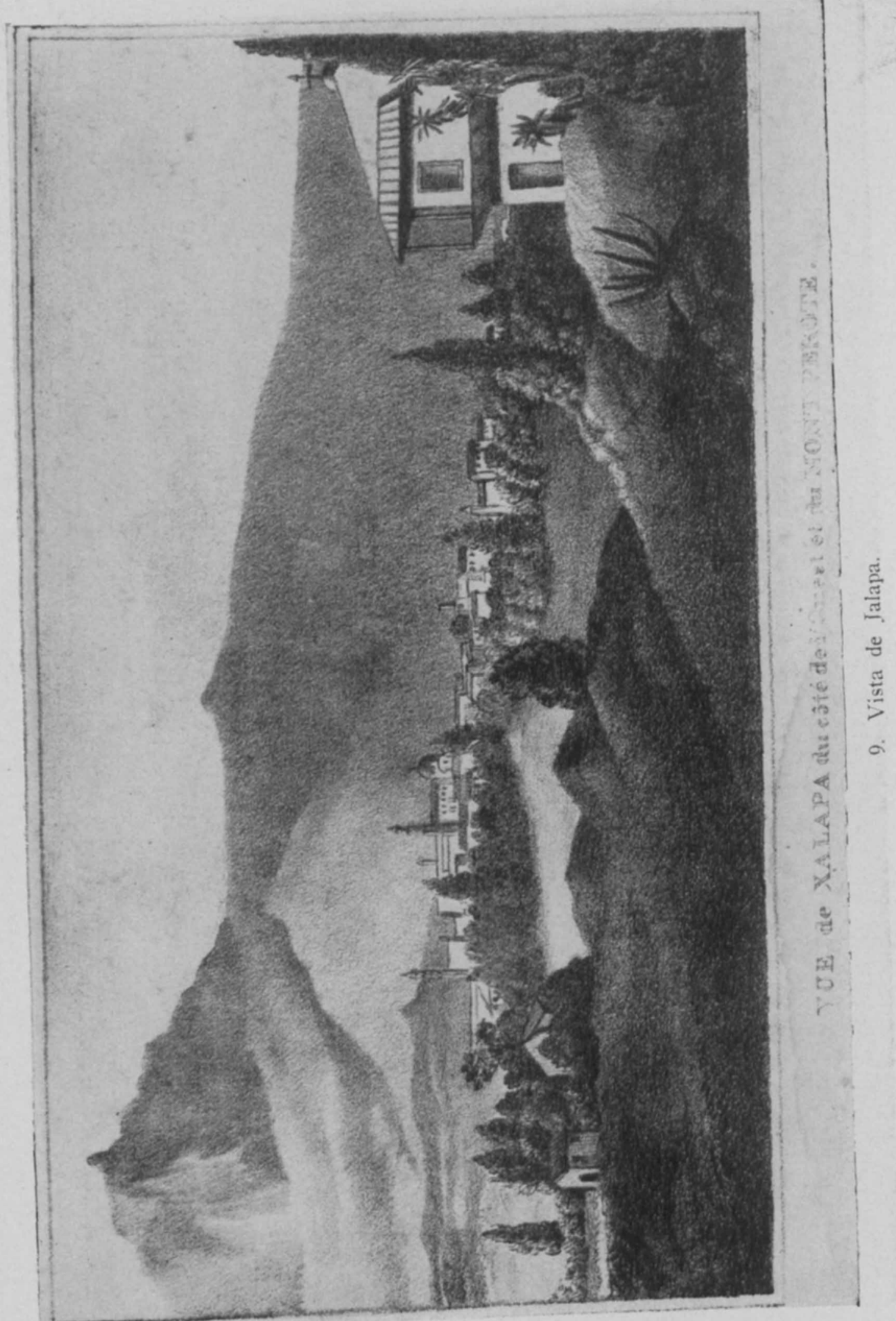


DOI: http://dx.doi.org/10.22201/iie.18703062e.1956.24.6oo

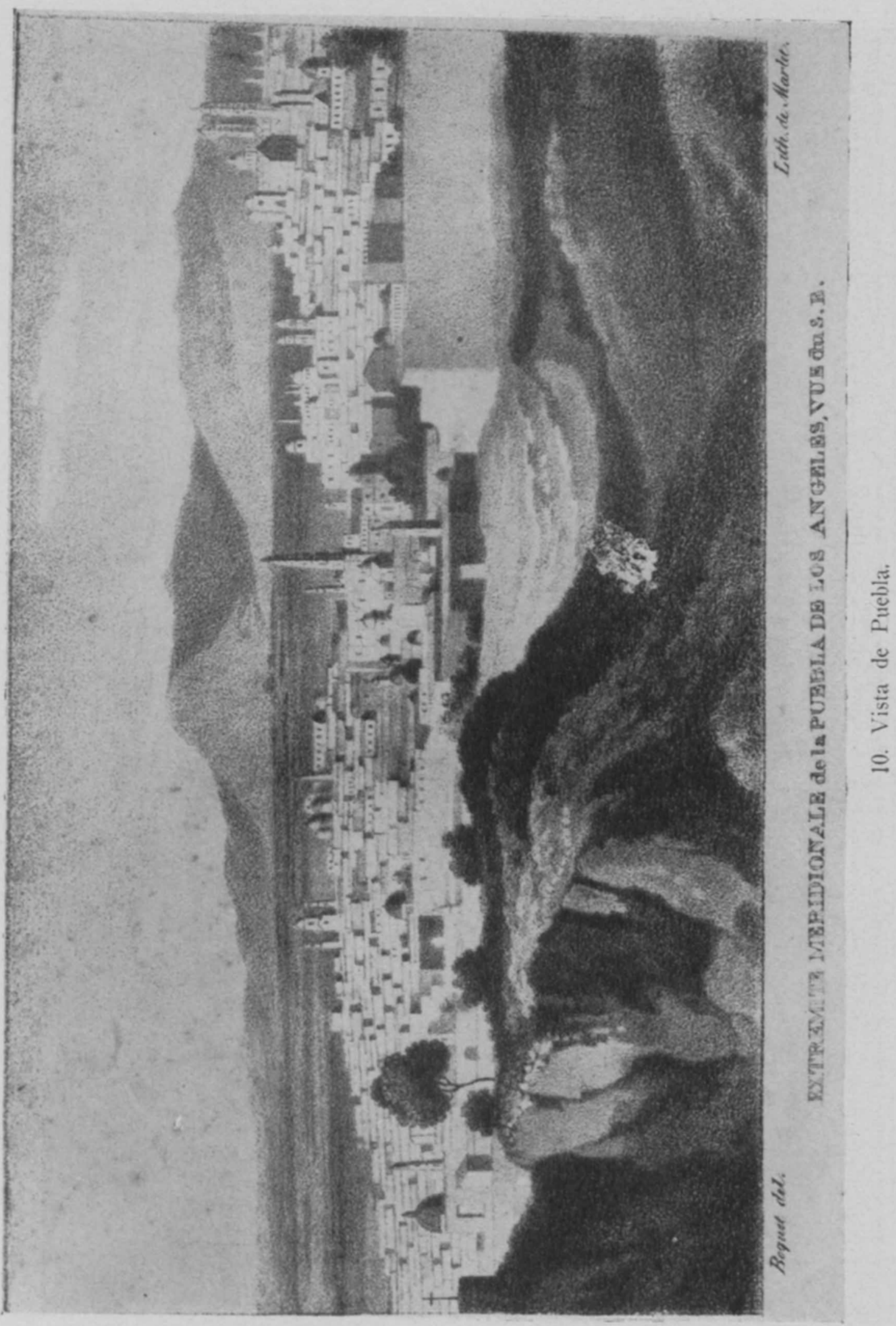




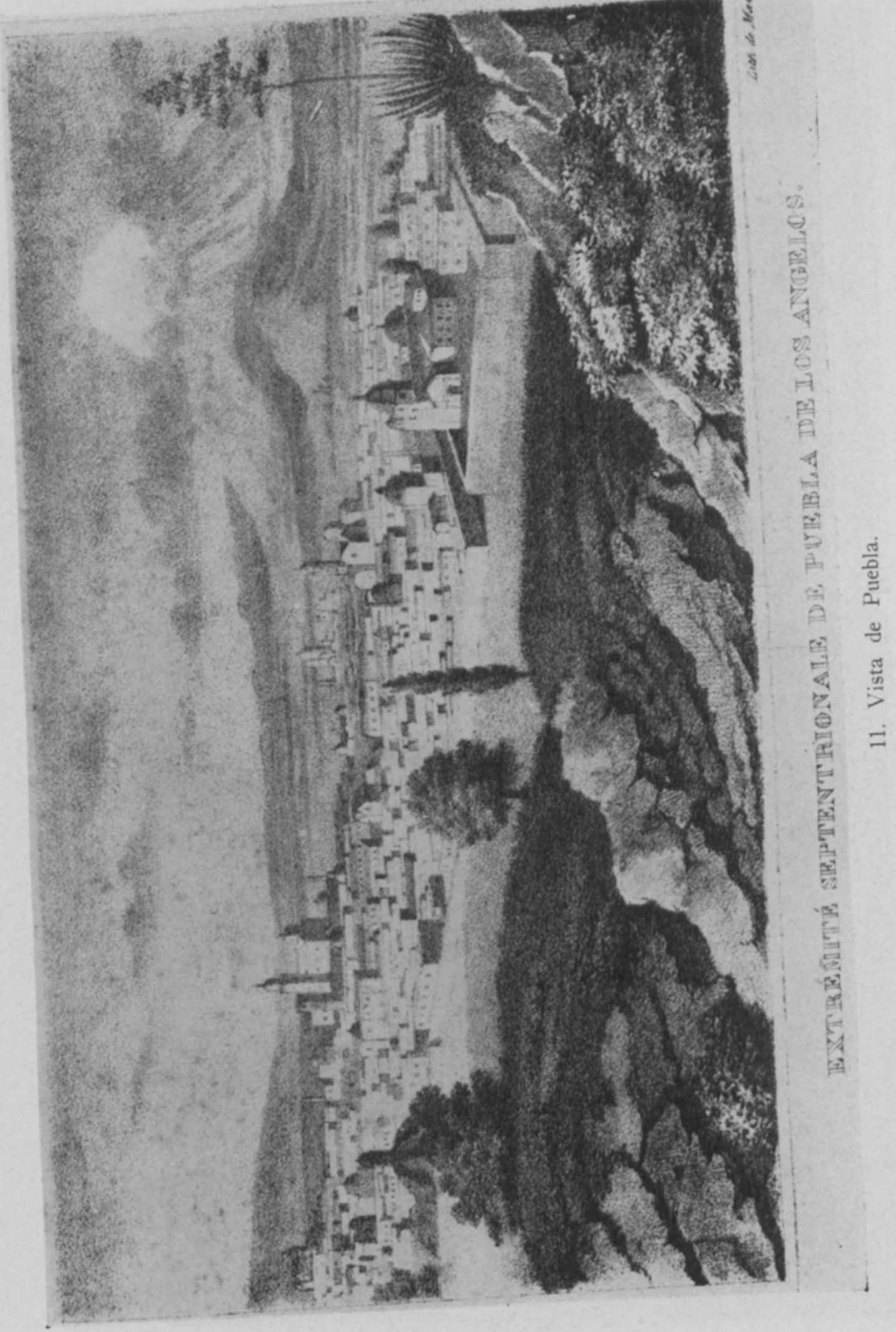




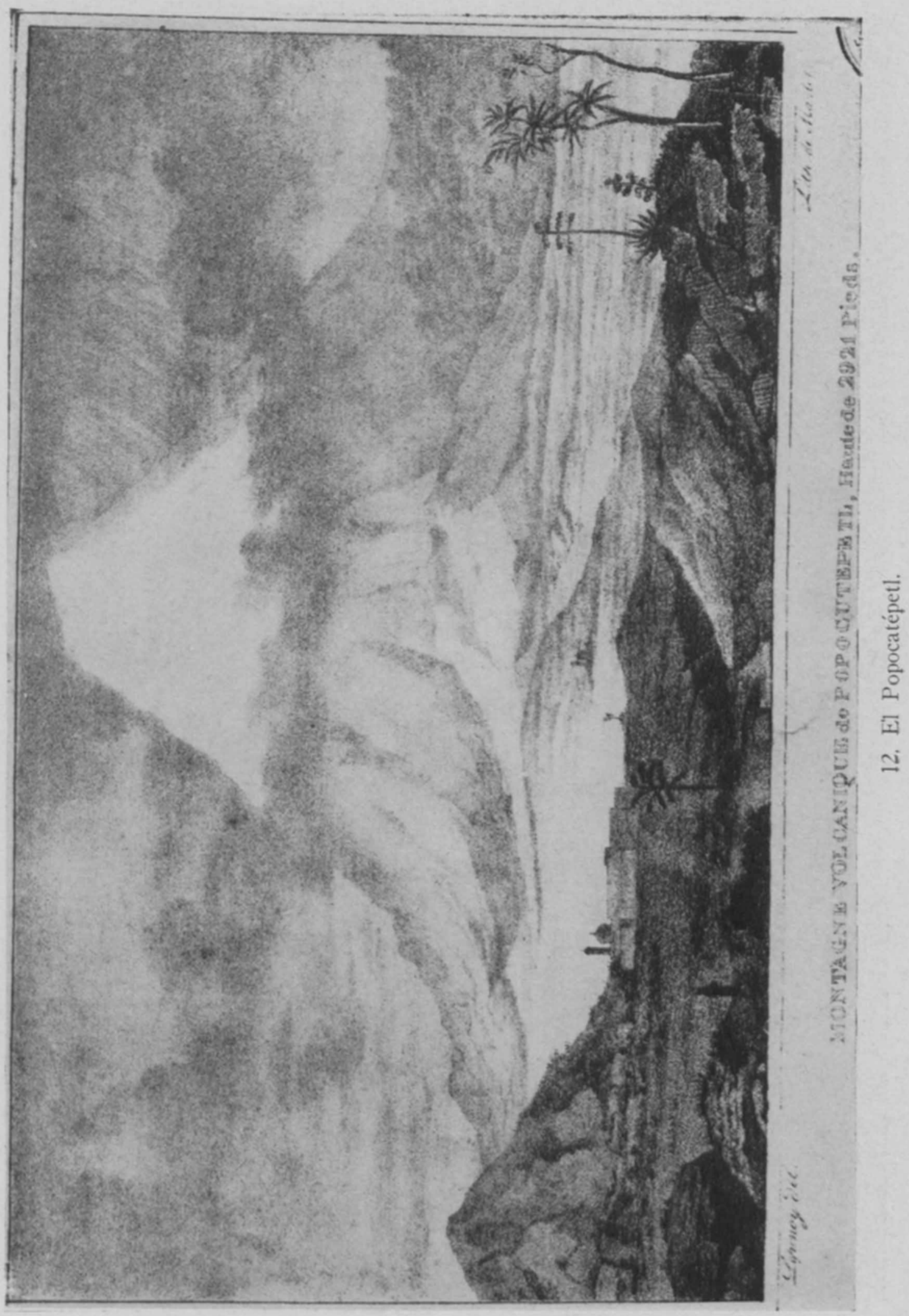


DOI: http://dx.doi.org/10.22201/iie.18703062e.1956.24.60o

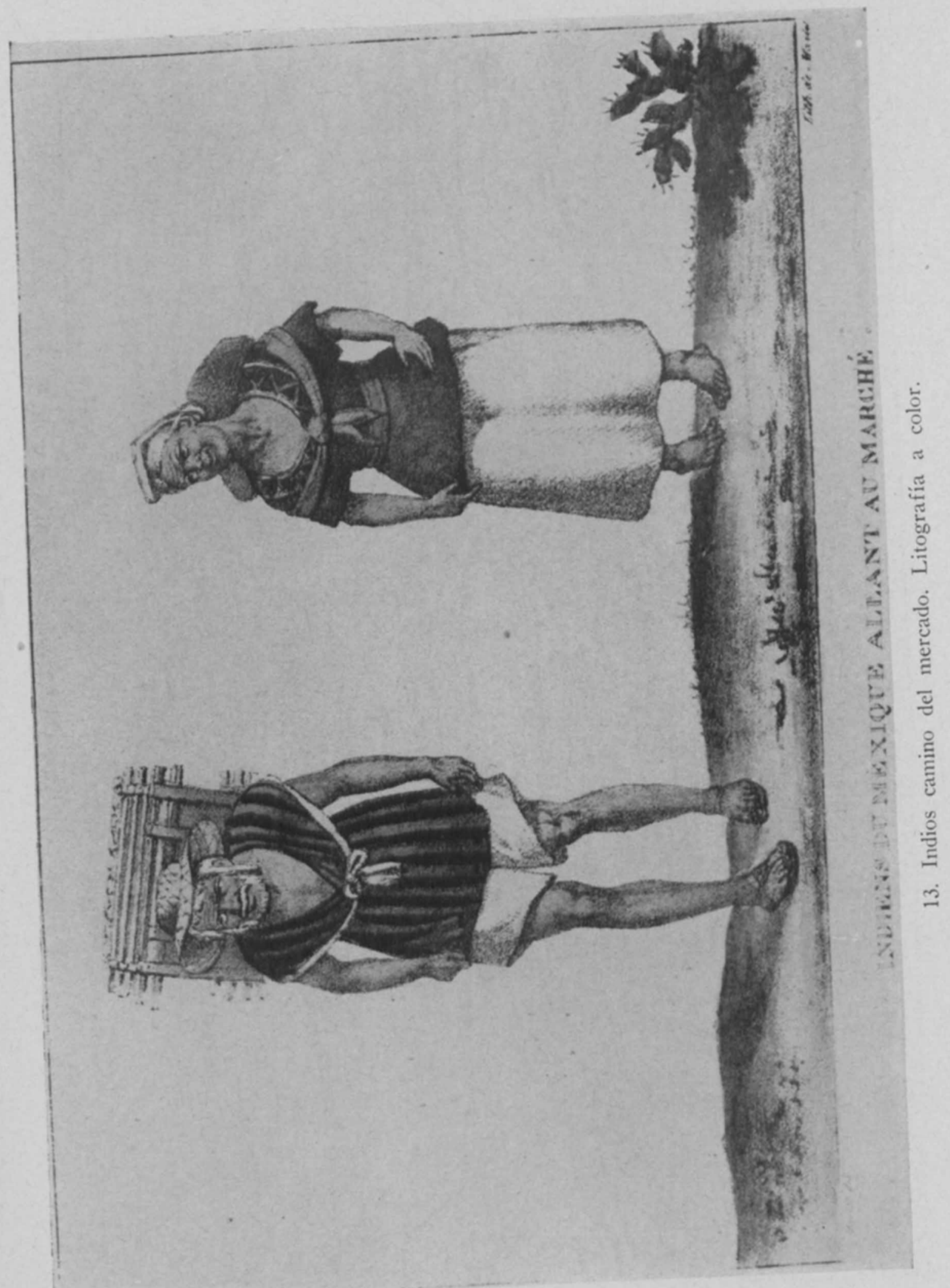


DOI: http://dx.doi.org/10.22201/iie.18703062e.1956.24.6oo

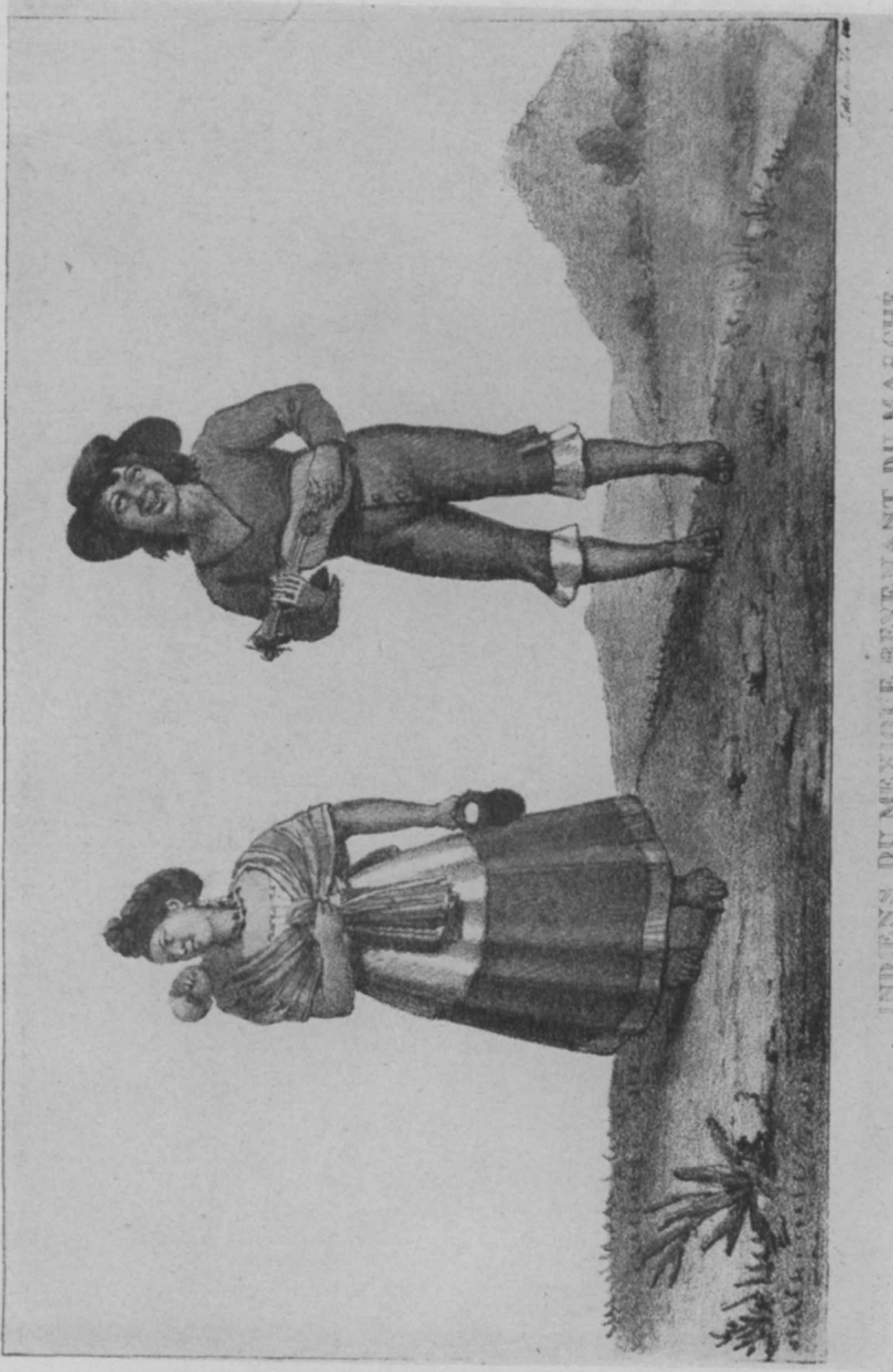




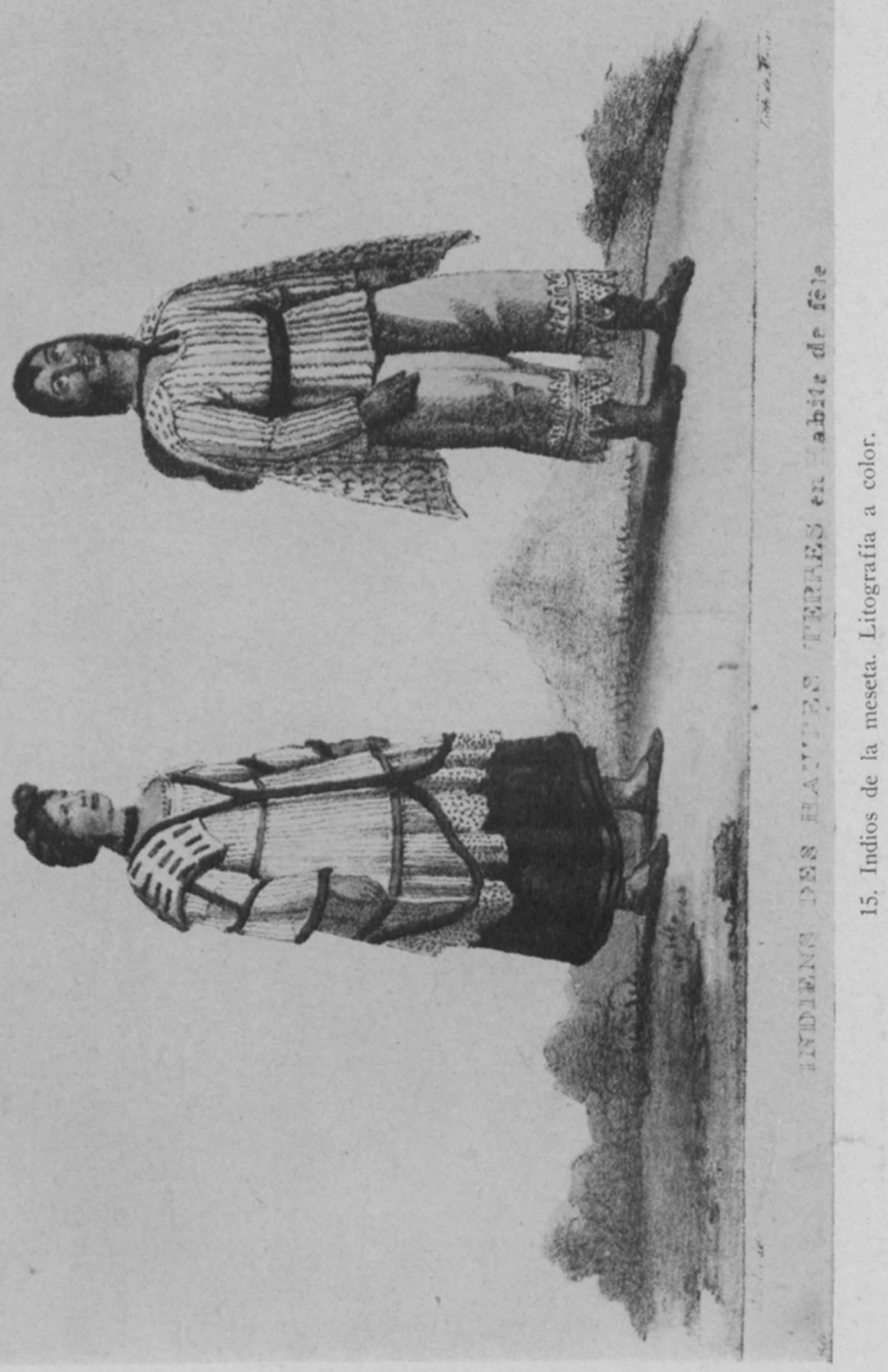




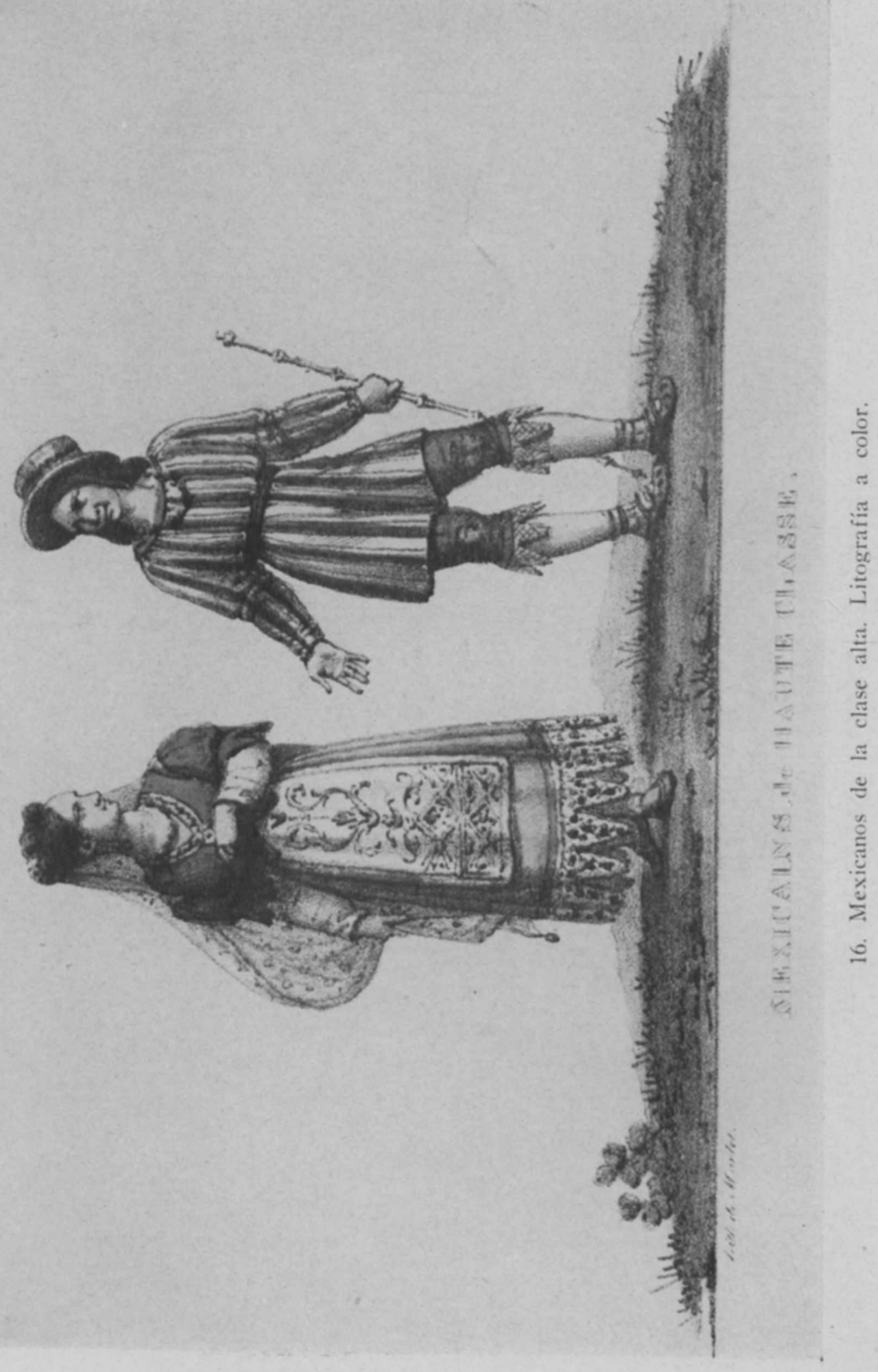


DOI: http://dx.doi.org/10.22201/iie.18703062e.1956.24.6oo

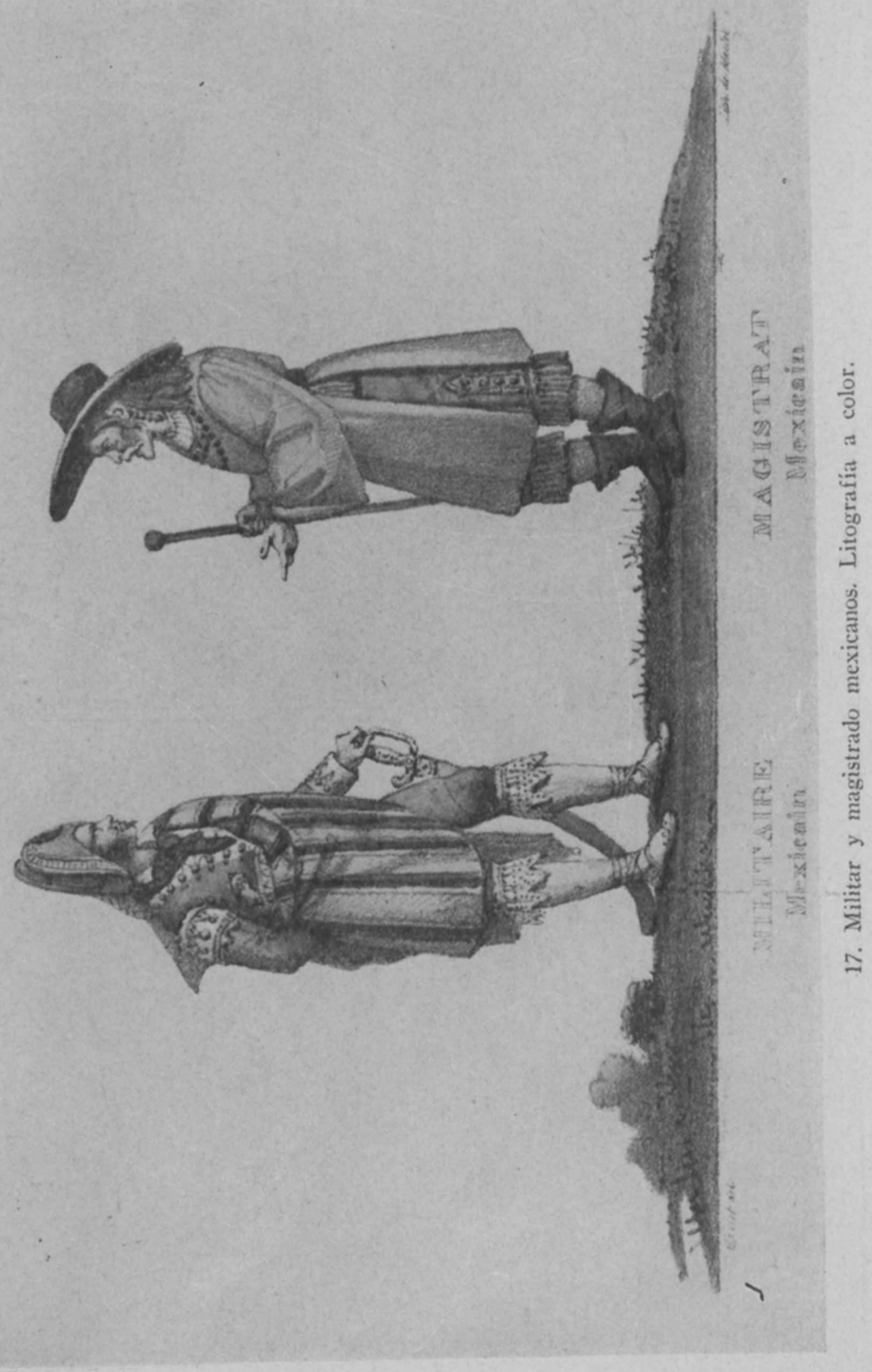


DOI: http://dx.doi.org/10.22201/iie.18703062e.1956.24.6oo

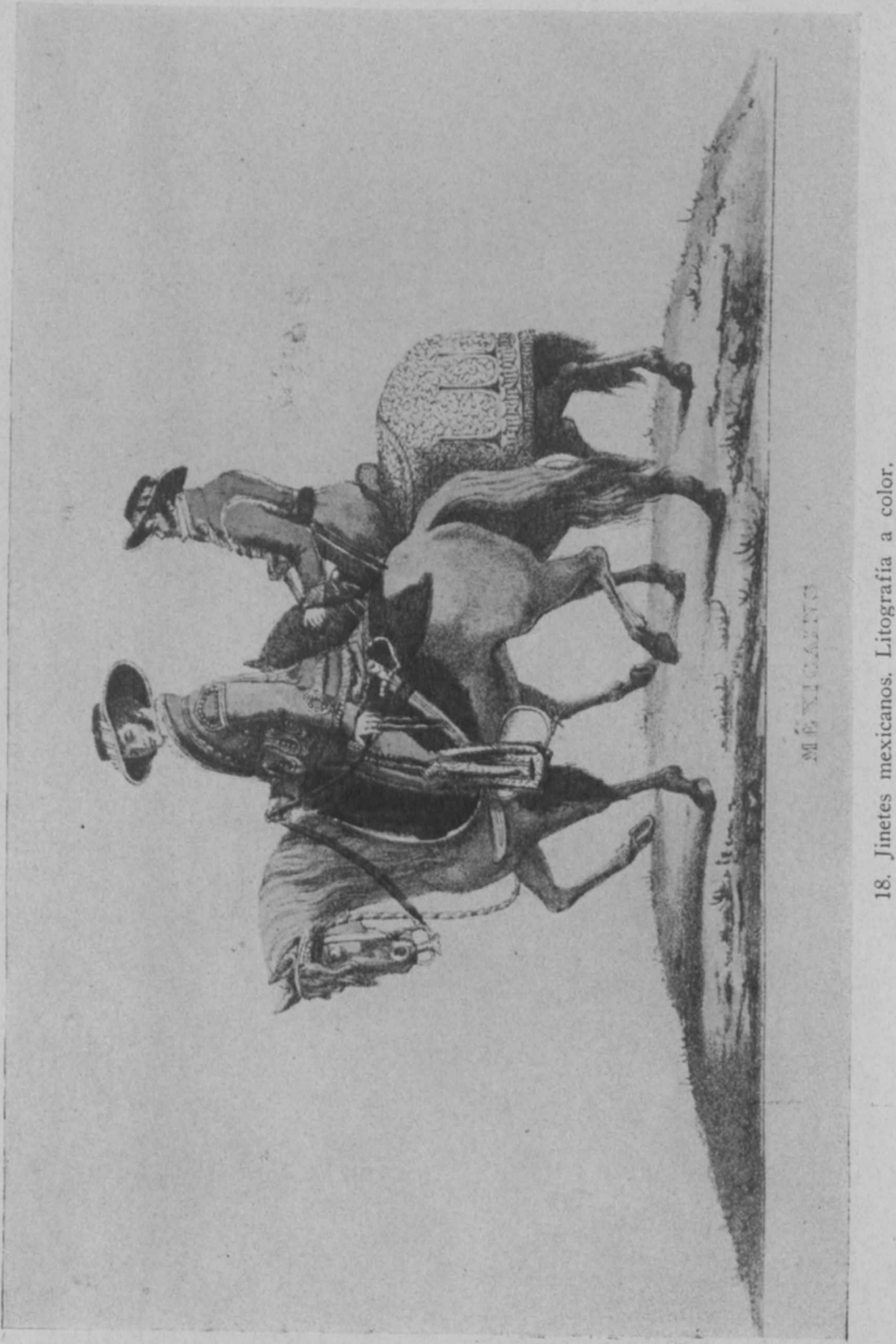




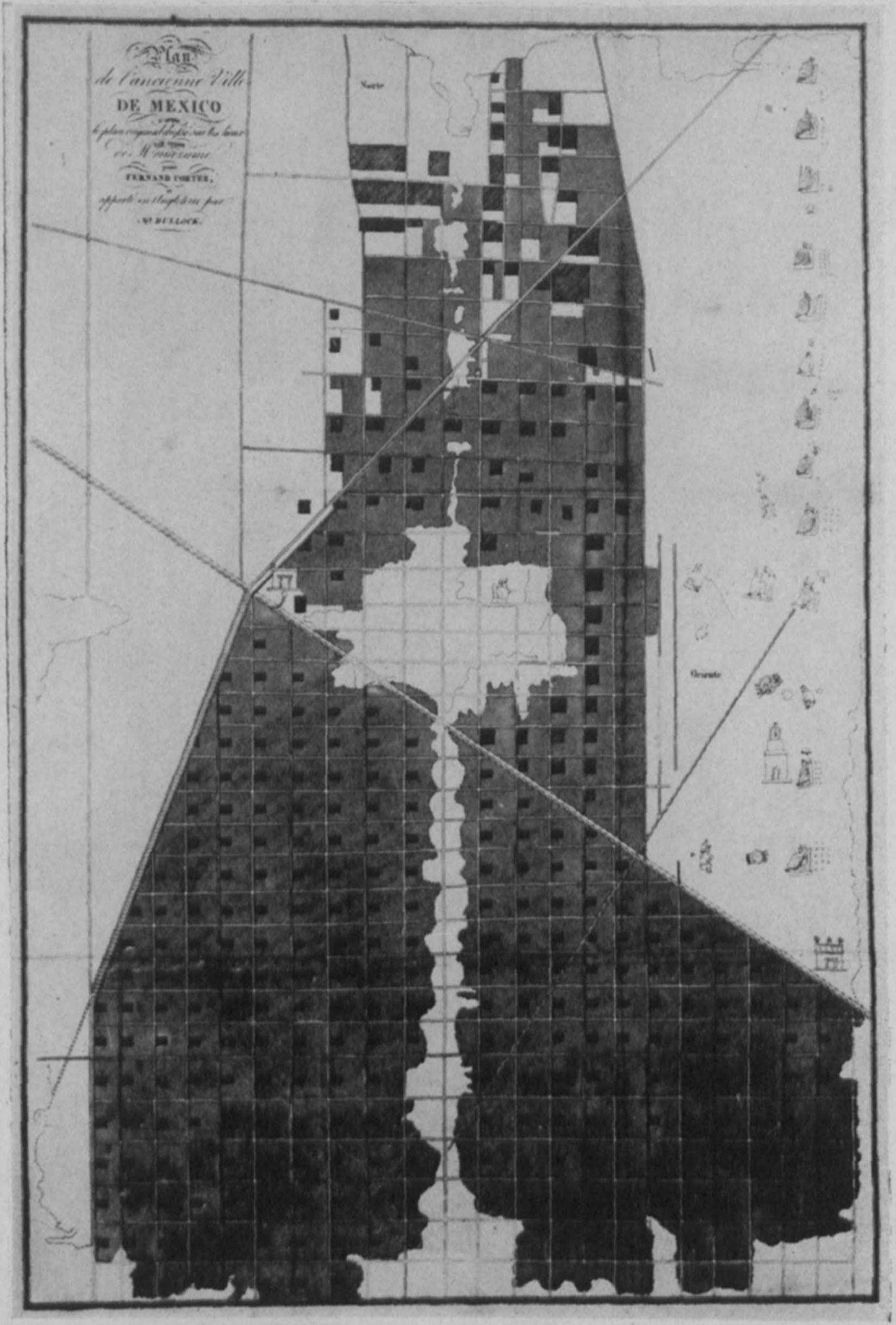

19. Plano llamado "de papel de maguey". Grabado. 
DOI: http://dx.doi.org/10.22201/iie.18703062e.1956.24.60o

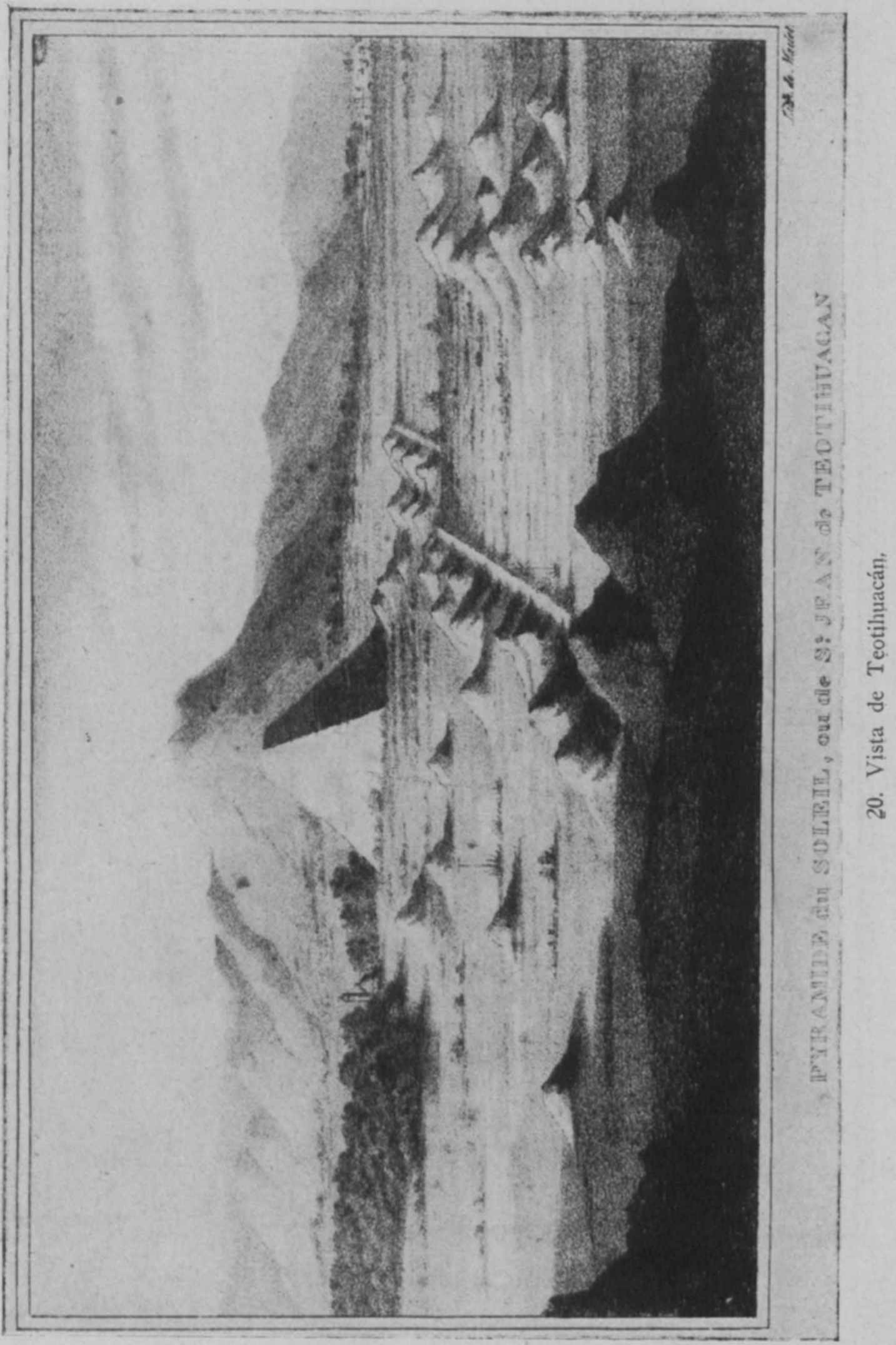


DOI: http://dx.doi.org/10.22201/iie.18703062e.1956.24.60o

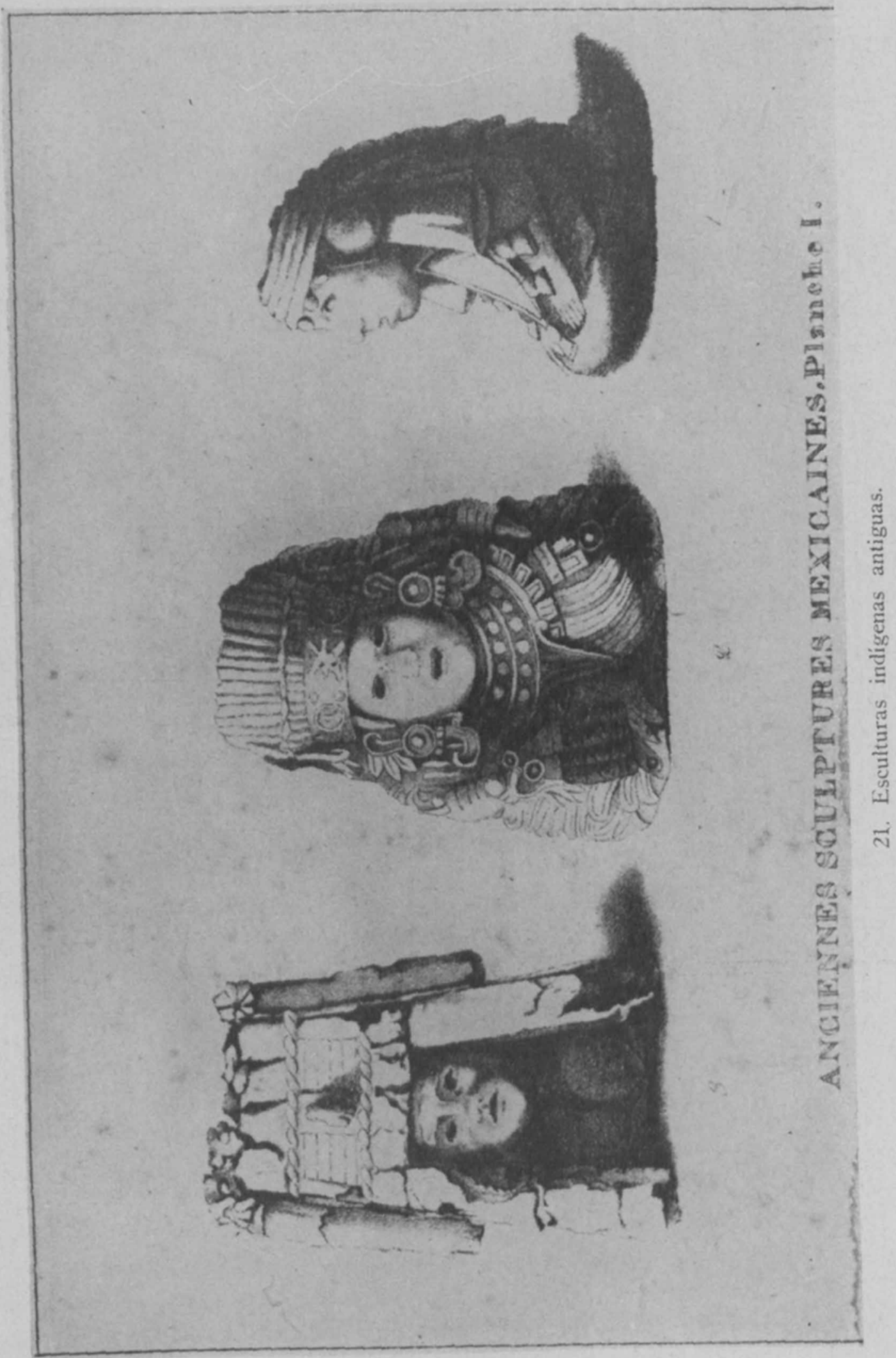


DOI: http://dx.doi.org/10.22201/iie.18703062e.1956.24.60o

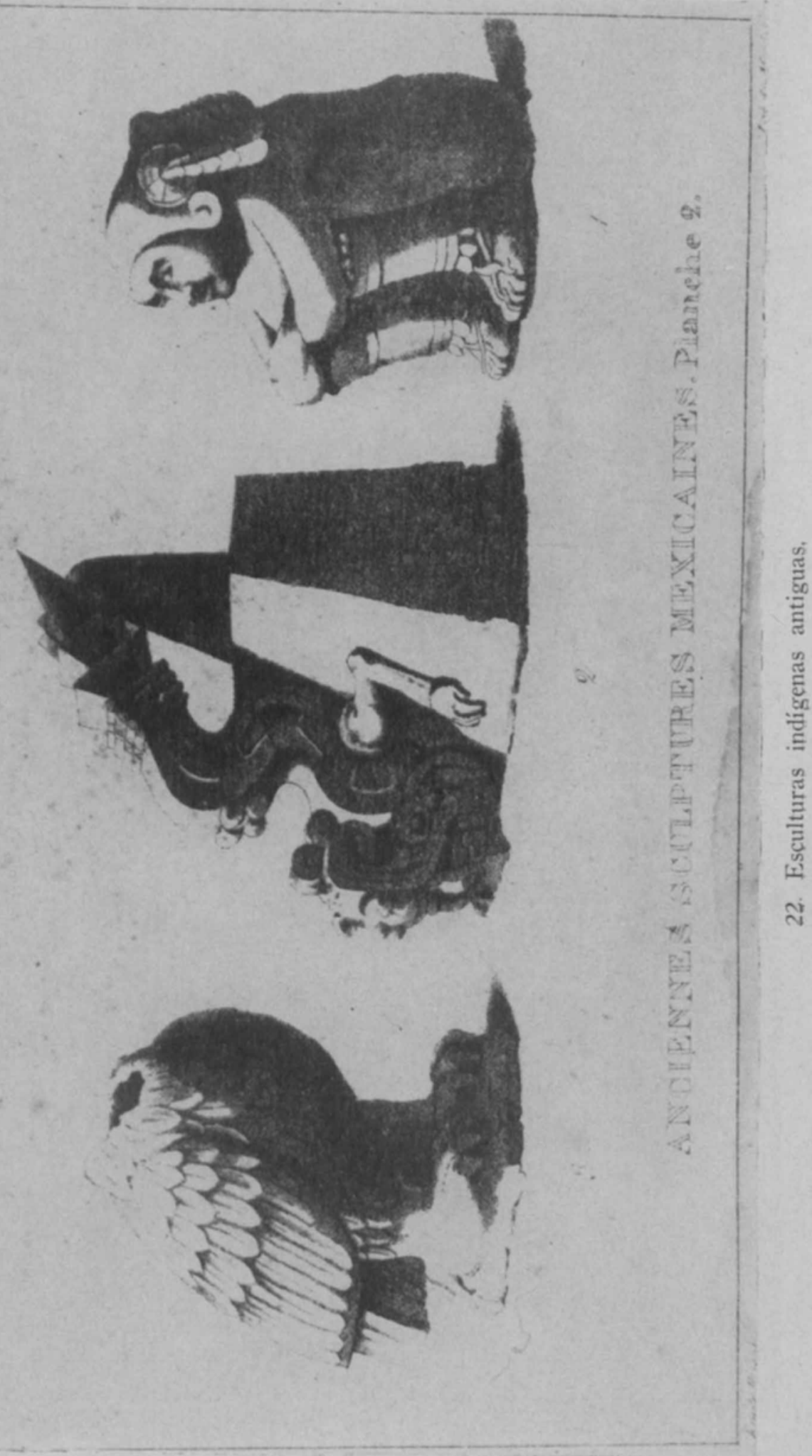


por los otros dibujantes. Mas veamos de qué se trata, considerando cada una de las láminas.

E1 Atlas contiene en primer lugar una litografía, sin firma, frente a la portada, con el retrato de "M. Bullock, Auteur de la narration sur le Mexique". Una advertencia dice: "Este Atlas, compuesto para el esclarecimiento del texto de la obra que publicamos, ha sido dibujado en los sitios mismos, por M. Bullock, y los temas han estado apoyados en todo aquello que pueda interesar o picar la curiosidad de los lectores". La lista de las planchas es la siguiente: 1. Plano de la antigua ciudad de México, levantado por orden de Moctezuma, para Fernando Cortés. 2. Plano de la ciudad de México, tal cual es actualmente, levantado y dibujado por el Coronel Conde García (sic), 3. Vista del Valle y la Ciudad de México, desde Tacubaya. 4. Puerta del Canal de Chalco a México. 5. La Vera-Cruz, vista desde el mismo punto, lado sur. 7. Vista de Jalapa, del lado Este. 8. Jalapa, del lado Oeste; con la Montaña de Perote. 9. La Puebla de los Angeles, lado sureste. 10. La Puebla de los Angeles, lado norte. 11. Indios camino del mercado. 12. Indios de vuelta del mercado. 13. Indios de las tierras altas, o mesetas, en traje de fiesta. 14. Mexicanos de raza castellana. 15. Militar y Magistrado mexicanos. 16. Mexicanos a caballo, de raza castellana, habitantes del campo. 17. Montaña del Popocatépetl. 18. Pirámide llamada del Sol, en San Juan Teotihuacán. 19 y 20. Dos láminas conteniendo seis piezas de la antigua escultura azteca.

Además, cada una de las láminas va precedida de explicaciones, en el orden anotado.

Nosotros las agruparemos de manera distinta: 19 , Retrato de W. Bullock. $2^{\circ}$, Plano de la ciudad de México. $3^{\circ}$, "Vistas" (9 en total). $4^{\circ}$, Trajes ( 6 en total). 5\%, Arqueología ("Plano de la antigua ciudad de México" y tres láminas más).

Sin duda la excelente litografía con el retrato de Bullock [2] es de algún artista francés, pues carece de los titubeos del dibujo que se esperan de un dibujante aficionado; por el contrario, la actitud y la construcción de la cabeza y el rostro son perfectas, aunque tengan su miaja de idealismo. No parece ser obra de su hijo, a juzgar por las otras láminas. 
El plano de la ciudad de México [3], fechado en 1824, es uno de tantos que provienen del levantamiento que hizo en 1793 el Teniente Coronel de Dragones Don Diego García Conde; fue el primer levantamiento científico y su original fue grabado en grandes y espléndidas planchas en 1807, por José Joaquín Fabregat, y Rafael Ximeno y Planes contribuyó con los dibujos de vistas y adornos que lo enriquecen y completan. Este grabado que se incluye en el Atlas es de pequeña escala, pero muy bien ejecutado, en el cual no aparecen los adornos del original, ni tampoco su verdadera procedencia, aunque sí el nombre de su autor, pero equivocado, pues se lee: "le Colonel Comte Don Diego García"; tomaron el apellido por título nobiliario. En la explicación de la lámina se dice "... una de las ciudades más extendidas y más regulares que existen... las iglesias, sobre todo la Catedral, son extraordinarias por su magnificencia interior..." Además se incluyen datos científicos de la posición de México.

En cuanto a las "vistas", todas reproducidas en litografía, son sin duda interesantes. La primera [4] es un panorama de la ciudad y Valle de México, tomado desde Tacubaya. Todo el primer término está ocupado por la que se supone ser la flora típica: palmas, cactus y magueyes; y más o menos al centro "... un indio ocupado en extraer el jugo de un maguey..." En otro término, a la izquierda se ve el Castillo de Chapultepec y más al fondo, a la derecha, se extiende un perfil de la Capital, un claro que parece el Lago de Texcoco y montañas recortándose en el horizonte. La composición es libre e ingenua, como el dibujo, si bien un árbol, al extremo derecho, ayuda a fijar el primer término.

Fantástica resulta en verdad la "Puerta del Canal de Chalco a México" [5]. La explicación dice: "Este canal que se comunica con los lagos de Chalco y Xochimilco, es la vía ordinaria por la que los indios llevan sus productos de caza y pesca en sus pequeñas canoas, al mercado de México". Pero la "vista" parece todo menos México. La puerta es de formas que recuerdan el Egipto, con palmeras a un lado, y la canoa no se parece nada a las típicas "trajineras"; en ella van seis personas 
coronadas de flores y dos de ellas tocando instrumentos de música; pero, la forma de la canoa, su adorno, la indumentaria y actitudes de los navegantes parecen más bien un remedo de la antigua Grecia. El neoclásico y los "exotismos" románticos hacían de las suyas. Se pregunta uno si existió tal puerta ( $y$ es seguro que nó) o si es un producto de la imaginación del dibujante, explicable porque al antiguo México se le veía muy cercano al antiguo Egipto. En todo caso es una curiosa visión, pero falsa.

Las dos "vistas" de Veracruz [6 y 7], desde el Castillo de San Juan de Ulúa ofrecen, además de unas lanchas veleras en el mar, sólo casi un perfil del puerto, en el que asoman torres y cúpulas de las iglesias. El texto explicativo dice: "El viaje a Veracruz, uno de los puertos más frecurentados de la Nueva España, es peligroso, sobre todo para los extranjeros, durante la temporada de lluvias; pero una parte de los inconvenientes de esa situación desaparecerán con una agricultura mejor entendida y algunas mejoras fáciles de efectuar, por una sabia administración. Esta ciudad, construída regularmente, contiene un gran número de iglesias y conventos..."

De Jalapa hay dos "vistas" [8 y 9], tomadas desde distintos puntos. La primera no muestra sino el camino y algunas casas humildes, en un paisaje montañoso. La lámina tíene encanto y cierta majestuosidad. De la segunda se puede decir lo mismo, si bien incluye un conjunto de la ciudad, vista a distancia. En la explicación se lee: "Esta ciudad, sobre la ruta de Veracruz a México, es la primera de alguna importancia que se encuentra, después de haber entrado en la región elevada..."

También de Puebla hay dos "vistas" [10 y 11] desde diversos puntos. La ciudad parece, en la primera lámina, muy oriental, por sus elevadas torres, exageradas sin duda, y sus cúpulas; pero es atractiva. En la segunda lámina surge al fondo, en último termino, el Popocatépetl, pero tan elevado que recuerda el Fujiyama. En el texto se lee: “... una de las principales ciudades de México; fundada por los españoles... sus edificios religiosos son magníficos y numerosos..."

E1 Popocatépetl, la "montaña volcánica" [12] es "la más elevada de las cordilleras de México. Su nombre es azteca y significa montoña humeante". En primer término un paisaje que sugiere el trópico, por la vegetación, aunque escasá, con la silueta de una población y una iglesia; a la izquierda un monte. Sobre el fondo - sin graduar bien los diferentes términos - se levanta con acusada forma cónica el Popocatépetl, dividido en dos zonas por una faja de nubes, siendo la superior completamente 
blanca para indicar que se trata de la región de las nieves eternas. Esta es la última "vista" del grupo.

Costumbres y trajes de México causaron siempre sorpresa a los viajeros del siglo $\mathrm{xIx}, \mathrm{y}$ los supieron ver $\mathrm{y}$ reproducir con precisión $\mathrm{e}$ interés. Bullock, a la manera de Linati, pero anticipándose a él, los presentó en litografías a color.

Unos "Indios de México camino del mercado" [13] dan oportunidad al dibujante de fijar su atención sobre una pareja de viejos, vestidos típicamente y cargados con sus mercancias, ella con un bulto, él con un huacal. Si bien el tono de las carnes es moreno, contrastando con el pelo blanco de las figuras, en verdad les falta carácter, aunque éste proviene de las indumentarias, y para darle ambiente a la lámina, que tiene, como todas, el fondo en blanco, sobre el piso, a la izquierda, un pequeño y espinoso nopal cumple ese objeto. Es curioso que ambas figuras tengan los pies hacia adentro, como si fueran zambas. En la explicación se dice: "Los trajes de estos indios están hechos de telas de algodón del país, que ellos mismos fabrican..."

Los "Indios de regreso del mercado" [14] llevan distinta indumentaria: "Los trajes de estos indios, un poco más cuidados que los anteriores, son igualmente de tela del país, o de cuero, que saben preparar. El traje del hombre es de este material. La mujer, siguiendo las costumbres de sus gentes, carga al niño en una canasta con provisiones, mientras el marido, un poco borracho de pulque $\longrightarrow$ de aguardientese divierte tocando la guitarra al caminar." Todo lo anterior es verdad, pero el traje y el tipo del hombre no tienen carácter mexicano; con su traje de cuero y su sombrero de fieltro, al parecer, podría ser un campesino europeo. Los pies de las figuras están muy mal dibujados; pero toda la lámina es interesante y hay un intento de paisaje montañoso.

Sorprendentes resultan los "Indios de las regiones altas en traje de fiesta" [15] porque si bien sus trajes parecen mexicanos tienen ciertas extravagancias que quizá fueron habituales en su tiempo, como el calzón rematado por una especie de encaje formando picos, o la capa del hombre que parece imitar piel de tigre. La túnica de la supuesta india, de tela vaporosa, resulta extraña con las listas rojas y los pesados adornos de los hombros. "Estos trajes - dice la explicación- no faltos de elegancia 
son los de los indígenas habitantes de los pueblos cercanos de Xalapa en los días de fiesta. Los colores son siempre brillantes..." Ahora bien, los tipos indigenas vuelven a ser deficientes en cuanto al carácter.

Las sorpresas van en aumento en las láminas siguientes. $\mathrm{La}_{a}$ de los "Mexicanos de la clase alta" [16], o como se lee en la lista de ilustraciones: "Mexicanos de raza castellana", parece ser producto de la fantasía. Aquí, claro está que los tipos son más adecuados. La mujer tiene belleza y distinción y su indumentaria, por el delantal bordado, recuerda el traje valenciano; la falda termina en picos y un gran velo sujeto a la cabeza flota garbosamente. Las faldas terminadas de la manera dicha quizá eran comunes entonces, las más antiguas de las "chinas poblanas" son asi, pero también acabaron por ser distintivo de las mujeres galantes, de donde viene el dicho de "irse de picos pardos", es decir, ir de parranda. Mas, sin duda, en 1824 tal moda pertenecía a la clase criolla de buena posición social y económica. Ahora bien, si el traje de la mujer parece ajustado a la realidad, el del hombre resulta más europeo y anticuado, más bien parece un personaje de alguna farsa; sus pantalones cortos terminados en picos, su corta túnica, su sombrero, la vara que empuña y el pelo largo hasta los hombros le dan un aire juvenil y lo hacen, casi, una figura salida de los naipes.

Dos figuras más en la siguiente lámina: "Militar y magistrado mexicanos" [17] enriquecen la colección de estrafalarios personajes que presentaba a los mexicanos en Londres y París en 1824, según la visión de los dibujantes ingleses y franceses. El militar es una figura bizarra, con su sombrero "napoleónico", pero en realidad a la usanza española del siglo XviII, con la redecilla que cuelga sobre su nuca y que sujeta el cabello; lleva una amplia capa listada y pantalones cortos terminados en picos de encaje; en el costado derecho asoma la cacha de la pistola y apoya la mano izquierda sobre la empuñadura del sable. Esta figura tiene particular interés porque muestra la indumentaria militar en el momento anterior en que fué renovada - gracias a los empréstitos-y se le dió un aspecto moderno, según el gusto inglés; se dotó a los oficiales del ejército con cascos a la griega y a los soldados con sombreros de fieltro de copa baja y ala corta. Una comparación entre el militar de esta lámina y los que incluye Linati ${ }^{6}$ en sus preciosas litografías, cuatro años después

6 Costumes civiles, militaires et religieux du Mexique, par Claudio Linati (Bruselas, 1828). Este interesante libro, que contiene 48 litografits a color y textos de Linati, será publicado próximamente por el Instituto de Investigaciones Estéticas, en edición facsimilar y con un estudio y traducción de Justino Fernández. 
(1828), dará idea de las transformaciones que se estaban llevando a cabo. En cuanto al Magistrado es evidente que su indumentaria es inventada, pues pertenece, al parecer, al siglo Xvir francés; aquí el delineante y litógrafo Marlet debe haber compuesto la figura según su imaginación, inspirándose en alguna estampa europea antigua. Lo gracioso es que en el texto se lee que: "... representa sin duda un alcalde indigena", lo cual es irrisorio a todas luces.

Por último, los "Mexicanos a caballo" [18] son dos gallardos criollos cuyas indumentarias sí están tomadas de algún apunte del natural. Uno de los caballos se cubre con una anquera, que llamaba la atención de los extranjeros. El texto de la explicación de la lámina es gracioso e inexacto por demás, dice asi: "Caballeros campesinos, descendientes de los conquistadores de México, forman la clase media del país. La manera en que sus caballos van equipados recuerda los tiempos de Cortés. Sus trajes también son de tipo antiguo". Tan despistado andaba el publicista, escritor, o quien haya organizado el Atlas, o todos juntos, que le parecen "de tipo antiguro" los trajes que sí se usaban y, en cambio, toma por "un alcalde indigena" a un figurín que quizá confeccionaron en Port-Royal. En todo caso, esta lámina de los caballeros es la mejor por su dibujo, gracia, gallardía y por estar más cerca de la realidad que las otras. Aquí también se impone la comparación con alguna de las litografias de Linati.

En conjunto este grupo de seis láminas a color con tipos e indumentarias supuestamente mexicanos, nos da idea de las falsedades en que se incurria, de buena $f e$, aunque no siempre, al presentar a la curiosidad europea las costumbres mexicanas. Por otra parte siendo estas litografías anteriores a las de Linati, en unos años, tienen el interés de ser su antecedente, pero, al mismo tiempo, ponen de relieve el sentido de observación, la veracidad y la calidad de la obra del artista italiano.

La parte de arqueología que se encuentra en el Atlas se inicia con un grabado [19] cuya inscripción, traducida, es la siguiente: "Plano de la antigua ciudad de México, según el original levantado en el lugar por orden de Moctezuma para Fernando Cortés y llevado a Inglaterra por W. Bullock." Ya se ve cuan lejos iba la fantasía de Bullock, quien creía que se trataba en efecto del plano de la parte central de Tenochtitlán; leamos: “... la parte de enmedio ha sido rota, sin duda porque representaba el espacio ocupado por el gran templo... Se creía que esta pieza 
había sido destruída ... pero se volvió a encontrar entre las colecciones del sabio Boturini y el gobierno mexicano la confió a M. Bullock... para que hicieran un grabado en Londres." $\mathrm{Y}$ éste es el que se reproduce.

En verdad se trata del códice post-cortesiano, conocido como el "Plano de Papel de maguey", que ahora conserva el Museo Nacional de Antropología e Historia. El códice fue prestado, en efecto, a Bullock y devuelto más tarde gracias a las gestiones de don Lucas Alamán. La primera idea de la localización de la parte correspondiente al plano en la Antigua Tenochtitlán vino, pues, de Bullock (1824), pensando que era la parte central; la segunda localización fue de Maudslay (1910), quien creyó que correspondia al rumbo de Santa María la Redonda; la tercera localización, y creo que la definitiva, fue llevada a cabo por Manuel Toussaint y por quien escribe ${ }^{7}$ en el estudio sobre los "Planos de la ciudad de México" (1948). Allí se verá que el plano corresponde a la región noreste de la ciudad, al barrio adyacente a Tlaltelolco; en el cruce de las diagonales más importantes vino a quedar la Garita de Peralvillo. Aunque bastante fiel al original, el grabado no da idea completa del códice; se le suprimieron las leyendas en español y se simplificaron todos los detalles, de manera que todo el sistema de calles y canales se pierde, así como muchos signos indígenas. No obstante es un interesante grabado que debió intrigar a los europeos $\mathrm{y}$, a lo menos, les haría pensar en el orden excelente que tenía Tenochtitlán. Ahora bien, que el plano fué levantado por orden de Moctezuma para Cortés, es una idea que inventó Bullock y que no deja de ser una noticia sensacional para su tiempo.

La "vista" de Teotihuacán [20] es interesante y está tomada desde la Pirámide de la Luna; ailí se advierte la "Avenida de los Muertos", o sea el gran eje central, si bien, hacia el sur se rompe la continuidad. La Pirámide del Sol está deformada y no da ni remota jdea de su magnitud y cuerpos escalonados. Otros innumerables montículos aparecen en varios sitios, como indicando que aún no se habían explorado. Un bosquecillo a la izquierda y unas montañas al fondo completan el panorama, cuyo primer término se marca en sombras oscuras. En el texto explicativo se lee: "Estos antiguos teocallis... se parecen a las pirámides de Egipto. Los dos grandes... están rodeados -como los monumentos

7 Planos de la ciudad de México. Siglos XVI y XVII. Estudio histórico, urbanístico y bibliográfico por Manuel Toussaint, Federico Gómez de Orozco $(y)$ Justino Fernández. México, 1948. XVI ${ }^{\circ}$ Congreso Internacional de Planificación y de la Habitación. Instituto de Investigaciones Estéticas de la Universidad Nacional Autónoma. 
egipcios llamados de Chéops- de un cierto número de pirámides más pequeñas, arregladas simétricamente. Su destino es desconocido. Se supone que los grandes estaban dedicados a los dioses y que las menores eran tumbas de personajes importantes." Ya se ven las ideas del tiempo acerca de las antigüedades mexicanas.

Las dos últimas láminas [21 y 22] contienen cada una las imágenes de tres esculturas indigenas antiguas. De la primera se dice que es la "estatua de una princesa" (a la derecha) y que "tiene gran semejanza con la esfinge egipcia" (!) ; la segunda (al centro) es "... ejemplo muy curioso de escultura mexicana, ejecutada en piedra muy dura ... busto de un sacerdote, o de un ídolo que representa el sol"; la tercera (a la izquierda) es un "busto de mujer en piedra de lava... Esta cabeza se parece a la Isis Egipcia". En la última lámina la figura a la izquierda se supone que es una "mujer sentada" (!) y su "cabeza tiene absolutamente el mismo carácter que distingue a los indios actuales"; la escultura central es un "idolo de piedra... representa la parte anterior de un cocodrilo y termina en ornatos sagrados... parece que es la única en su género que ha sido descubierta"; la escultura representada en el extremo izquierdo es: "El águila mexicana... La ciudad de México siempre se representa por un águila... se cree que ésta perteneció al Palacio de Moctezuma." 8

En resumidas cuentas ¿qué es lo que podía "interesar o picar la curiosidad" del público europeo, con respecto a México, a principios del siglo XIX? Primero, los planos y "vistas" de ciudades y la naturaleza americana; segundo, los trajes y costumbres y, tercero, la arqueología.

Del primero de esos intereses sorprende a la mirada extranjera el número $\mathrm{y}$ la magnitud de las iglesias. Del segundo, los trajes $\mathrm{y}$, sin duda, la moda de rematar por abajo faldas y pantalones en picos, desde el humilde campesino hasta el criollo rico y el militar; es curioso que los "piços" acabaran por tener una connotación especial. En todlo caso se trataba de presentar variados tipos de las diferentes clases sociales. Del tercer interés, la arqueología, resalta el empeño de emparentar el México antiguo con Egipto, idea común en el tiempo y aun después.

8 Esta escultura mutilada, o decapitada, parece ser la que se encuentra a la entrada del Edificio Boker; a lo menos es muy semejante. 
En cuanto al valor artístico de las láminas, hay que juzgar a éstas por partes. Ya se dijo que el retrato de $\mathrm{M}$. Bullock es de algún litógrafo profesional y excelente dibujante. Los grabados de la ciudad de México, antigua y moderna son buenos y sin mayor interés. Las "vistas" y dibujos de arqueología son ingenuos, en general, y ciertamente no de mano maestra. Las láminas a color con tipos y trajes son, sin duda, las más atractivas, aunque sean disparejas en calidad y adolezcan de defectos de dibujo. Puede suponerse, como se ha insinuado más arriba, que el hijo de Bullock hizo apuntes a lápiz de las "vistas", de algunos trajes y piezas arqueológicas, y que al delinearlos en definitiva para su reproducción litográfica los dibujantes franceses añadieron algo en su interpretación y aun inventaron, para completar, algo más también.

La presentación que hace de México y los mexicanos el Atlas es en parte verdadera y en parte falsa. Con buena fe se ofrecia un México atractivo e interesante en varios aspectos y para ello fué necesario, en algunos casos, completar los conocimientos con la fantasía y hacer a nuestros indios lo más parecidos que fuera posible a los europeos. Todavía hoy cuesta esfuerzo hacer que los extranjeros dejen de vernos como una "curiosidad americana" y que tengan hacia nuestro país una más profunda y amplia comprensión. México aun es una novedad en muchos sentidos. 